Удк 330.341 .1

\title{
ЕКОНОМІЧНО-ПРАВОВИЙ АНАЛІЗ РЕАЛІЗАЦІЇ «СТРАТЕГІЇ РОЗВИТКУ СФЕРИ ІННОВАЦІЙНОӦ ДІЯЛЬНОСТІ НА ПЕРІОД ДО 2030 РОКУ»
}

\author{
ECONOMIC AND LEGAL ANALYSIS \\ OF THE IMPLEMENTATION \\ OF THE «STRATEGY FOR DEVELOPMENT \\ OF INNOVATIVE ACTIVITY FOR THE PERIOD UNTIL 2030»
}

\author{
Дзюба Оксана Миколаївна \\ кандидат економічних наук, доцент, \\ Національний транспортний університет \\ ORCID: https://orcid.org/0000-0002-2411-5844 \\ Шевченко Ольга Євгенівна \\ аспірант, \\ Національний транспортний університет \\ ORCID: https://orcid.org/0000-0002-9996-7689 \\ Dziuba Oksana, Shevchenko Olha \\ National Transport University
}

\begin{abstract}
Стаття присвячена економічно-правовому аналізу «Старатегії розвитку сорери інноваційної діяльності на період до 2030 року» та впливу її на розвиток інноваційної діяльності в Україні. Було досліджено напрямки реалізації стратегії та окреслено низку проблем, які можуть впливати на її ефективну реалізацію та розвиток інноваційної діяльності вцілому. Встановлено, що на сьогоднішній день для ефективної реалізації стратегії важливим є узгодження нормативно-правової бази, яка регулює інноваційну діяльність, забезпечення фрункціонування інноваційної інфрраструктури, а також розвиток інноваційної культури суспільства, як необхідної складової економічних відносин, оскільки саме інноваційна культура забезпечує сприйнятливість людей до нових ідей, їх готовність і здібність підтримувати і реалізувати інновації в усіх ссрерах життя.

Ключові слова: інноваційна діяльність, інноваційне підприємництво, стратегія, нормативно-правове забезпечення, інноваційна інфрраструктура, інноваційна культура.
\end{abstract}

Статья посвящена экономико-правовому анализу «Старатегии развития сферы инновационной деятельности на период до 2030 года» и влияние ее на развитие инновационной деятельности в Украине. Были исследованы направления реализации стратегии и намечено ряд проблем, которые могут влиять на ее эффективную реализацию и развитие инновационной деятельности в целом. Установлено, что на сегодняшний день для эффективной реализации стратегии важно согласование нормативно-правовой базы, регулирующей инновационную деятельность, обеспечение функционирования инновационной инфраструктуры, а также развитие инновационной культуры общества, как необходимой составляющей экономических отношений, поскольку именно инновационная культура обеспечивает восприимчивость людей к новым идеям, их готовность и способность поддерживать и реализовать инновации во всех сорерах жизни.

Ключевые слова: инновационная деятельность, инновационное предпринимательство, стратегия, нормативно-правовое обеспечение, инновационная инфраструктура, инновационная культура.

The object of study of the article is the economic and legal support for the implementation of the "Strategy for the development of innovation for the period up to 2030." The corresponding strategy is one of the main documents whose main task is to achieve effective development of innovations in Ukraine. To implement the development of innovative economy and innovative activities in this document set a number of tasks, the solution of which should ensure rapid and high-quality transformation of creative ideas into innovative products and services. The solution of each of the set tasks today requires a thorough study of all related problems that exist in the development of innovation in Ukraine. Among the main problems that affect the effective implementation of the Strategy, the authors 
highlight the following: imperfect legal framework, lack of proper infrastructure, inefficient government policy in the field of innovation. If we talk about the shortcomings of legal legislation, a large number of scientists have come to the conclusion that the current innovation legislation of Ukraine is partial and unsystematic. The shortcomings of the legislation, which need to be harmonized as a matter of priority, are differences in the definition of the following terms: "innovation", "innovation", "innovation project", "innovation development system", "innovation policy", etc. Regarding the lack of quality innovation infrastructure, it should be noted that for the effective functioning of the system is important interaction and coherence between its actors. The authors also noted the importance of the existence of an innovative culture, which plays not the least role in the implementation of the Strategy. Innovative culture contributes to the awareness of economic actors of the relationship between the introduction of new knowledge and technology and the benefits of it. In order to effectively develop innovation in our country, it is necessary to eliminate a number of shortcomings that exist today. The study of existing problems made it possible to analyze the main directions of the Strategy implementation and suggest possible ways to improve them.

Keywords: innovative activity, innovative entrepreneurship, strategy, normative-legal maintenance, innovative infrastructure, innovative culture.

Постановка проблеми. В сучасних світових реаліях основним чинником, який визначає конкурентоспроможність держави, $€$ інноваційність ії економіки та можливості адаптуватися до сучасних швидких змін. За останні роки Ураїна активно починає розвивати свій інтелектуальний потенціал, зокрема і в розвитку інновацій та інноваційного підприємництва. Але, нажаль, на сьогоднішній день для розвитку інноваційної діяльності та інноваційного підприємництва в Україні створено недостатньо умов як в економічному плані, так і в правовому.

Аналіз останніх досліджень і публікацій. В основу стратегії лягли безліч фракторів, які прямо чи опосередково вливають на розвиток інноваційної діяльності та економіки в цілому. Як показує аналіз сучасної літератури та наукових праць, існує ряд вітчизняних та зарубіжних науковців, що також активно дасліджують інновації в підприємництві, зокрема: Балабанова Л.В., Сардак О.В., Ящишина І.В., Майлован В.В. та інші. Не зважаючи на велику кількість досліджень інновацій та інноваційного підприємництва, дане питання залишається не повністю розкритим саме з того боку, що стосується впливу відповідної Стратегії на розвиток та вдосконалення інноваційної діяльності в Україні.

Мета дослідження. Метою статті є проведення всебічного аналізу «Стратегії розвитку сорери інноваційної діяльності на період до 2030 року» як одного 3 основних документів, завданням якого $€$ сприяння есрективному розвитку інноваційної діяльності в Україні.

Виклад основного матеріалу. 32013 до 2018 років схвалено майже 40 стратегічних документів щодо розвитку інновацій, однак вони мають виключно галузевий характер (йдеться про Стратегію розвитку промислового комплексу України, Стратегію розвитку експорту продукції сільського господарства, харчової та переробної промисловості до 2026 року, Стратегія низьковуглецевого розвитку до 2050 року і т. ін.).

Для того щоб вирішити проблеми розвитку інноваційної діяльності та інноваційного підприємництва в Україні у 2019 році Кабінетом міністрів України була прийнята Стратегія розвитку сорери інноваційної діяльності на період до 2030 року (далі - Стратегія), основною метою якої стала розбудова національної інноваційної екосистеми для забезпечення швидкого та якісного перетворення креативних ідей в інноваційні продукти та послуги.

Основними завданнями, які виділяються в Стратегії $€$ [1]:

1. Створення сприятливого нормативноправового поля для суб'єктів господарювання, що провадять інноваційну діяльність.

2. Розвиток інноваційної інорраструктури, методично-консалтингове забезпечення, розширення зв'язків вітчизняних науковців і винахідників з іноземними підприємствами.

3. Підвищення рівня спроможності, що реалізується як шляхом культурно-просвітницької діяльності та підвищення інноваційної культури, так і через освітню діяльність, спрямовану на забезпечення успішної кар'єри молоді після завершення навчання у закладах вищої освіти за одним з обраних напрямів: започаткування власної справи, робота на підприємстві, що відповідає сучасному технологічному рівню, або наукова (викладацька) робота.

4. Збільшення фрінансування наукових досліджень на конкурсній основі з акцентуванням уваги на переході результатів, отриманих у рамках фрундаментальних наукових досліджень, у тематиці прикладних наукових досліджень і науково-технічних розробок, до фрінансування яких залучається бізнес.

5. Перегляд пріоритетних напрямів розвитку науки і техніки з метою їх наближення до напрямів, визначених у розвинутих державах 
світу, на основі сучасних світових технологічних трендів.

6. Створення у межах населених пунктів місць, призначених передусім для розгортання інтелектуальної, творчої діяльності, раціоналізаторського руху, розвитку креативних індустрій (зокрема виділення територій, створення на них відповідної інфрраструктури, надання інфрормаційно-аналітичного та методичного забезпечення розвитку інноваційної культури).

7. Створення із залученням світових експертів, тренерів, наставників, європейської мережі підприємництва (EEN) шкіл обміну досвідом та національних ресурсів з навчання підприємництву та інноваціям, зокрема мережі підвищення кваліфрікації як для викладачів, так і для керівників закладів вищої освіти та наукових установ.

8. Покращення якості освіти шляхом наближення її до потреб глобального ринку та потреб у фрахівцях, здатних створювати, адаптувати та використовувати технологічні інновації, підтримка запровадження навчальних дисциплін з підприємництва, фрінансової грамотності та охорони інтелектуальної власності.

Для реалізації поставлених завдань в Стратегії перш за все потрібно розв'язати низку проблем, існуючих на шляху розвитку інноваційної діяльності в Україні. На сьогоднішній день такими проблемами є:

- відсутність стимулювання інноваційної діяльності підприємств з боку держави зокрема, оскільки здебільшого вона проводиться за рахунок власних коштів підприємств;

- недосконалість заонодавчої бази зокрема відсутній належний правовий захист інтелектуальної власності;

- відсутність належної інсрраструктури та механізмів комерціалізації науковотехнічних розробок;

- неесрективна державна регулятивна політика та інш.

В самій Стратегії закладено ряд напрямів і способів розв'язання існуючих проблем та вирішення поставлених завдань. На рис. 1 зображено напрямки реалізації поставлених задач з розвитку інноваційної діяльності в Україні до 2030 року.

На наш погляд удосконалення кожного 3 цих напрямків реалізації Стратегії дозволить більш ефективно вирішити її завдання. Тому розглянемо детально кожен 3 зазначених напрямків.

Першим напрямком на шляху ефективної реалізації Стратегії $€$ створення сприятливого нормативно-правового забезпечення інноваційної діяльності в Україні.

Відповідний інтерес до даного питання насамперед пов'язаний 3 тим, що в результаті багатьох досліджень питання правового забезпечення інноваційної діяльності, майже всі науковці дійшли висновку, що чинне інноваційне законодавство України є частковим, фррагментарним, дезінтегрованим і безсистемним.

Для визначення оптимальних шляхів розвитку інноваційного законодавства України необхідно провести аналіз його сучасного стану і структури, з'ясувати наявність і достатність підстав для його систематизації, а також визначити правові форми ії здійснення 3 метою окреслення шляхів підвищення ефрективності та можливі напрямки подальшого розвитку національного законодавства про інноваційну діяльність.

Інноваційна діяльність, як і будь-який інший вид діяльності, має керуватися норами чиного законодавства України. Якщо аналізувати сучасну нормативно-правову базу, яка регулює відповідний вид діяльності в Україні, то в цілому ми можемо сказати, що на сьогодні в нашій державі майже створено законодавче підґрунтя для здійснення і розвитку інновацій але все ж за кількістю і якістю нормативних законодавчих актів українська нормативна база поступається подібним системам у розвинутих країнах світу.

В таблиці 1 відображено основні нормативно-правові акти основна задача яких регулювати та захищати інноваційну діяльність в Україні.

При здійснені аналізу існуючої нормативно-правової бази, яка регулює інноваційну діяльність Україні недоліками законодавчого регулювання, які потребують першочергово узгодження, $€$ розбіжності у визначенні таких термінів: «інновація», «інноваційна діяльність», «інноваційний проект», «система інноваційного розвитку», «інноваційна політика»тощо.

Так, наприклад термін «інноваційна діяльність» в Законі України «Про інноваційну діяльність» [6] визначається, як діяльність, що спрямована на використання і комерціалізацію результатів наукових досліджень та розробок і зумовлює випуск на ринок нових конкурентоспроможних товарів і послуг.

У Законі України «Про інвестиційну діяльність» [5] інноваційну діяльність визначено вже, як одну з форм інвестиційної діяльності, що здійснюється 3 метою впровадження 
Напрямки реалізації Стратегії

- Створення сприятливого нормативноправового забезпечення інноваційної діяльності

- Розвиток інноваційої інфраструктури

•Підвищення інноваційної культури

Рис. 1. Напрямки реалізації Стратегії розвитку сфери інноваційної діяльності на період до 2030 року

Джерело: розроблено автором на основі [1]
Завдання закладені в Стратегію

1. Створення нормативно-правового поля для суб' єктів господарювання, що провадять інноваційну діяльність

2. Перегляд та нормативно-правове закріплення

пріорітетних напрямків розвитку науки і техніки з метою їх наближення до напрямів, визначених у розвинутих

державах світу

1. Розвиток методично-консалтингового забезпечення, розширення зв'язків вітчизняних науковців і винахідників з іноземними підприємствами;

2. Створення у межах населених пунктів місць,

призначених передусім для розгортання інтелектуальної,

творчої діяльності, раціоналізаторського руху, розвитку креативних індустрій.

1. Підвищення інноваційної культури, через освітню діяльність, яка бде спрямована на забезпечення успішної кар'єри молоді після завершення навчання у закладах вищої освіти за одним з обраних напрямів:

започаткування власної справи, робота на підприємстві,

що відповідає сучасному технологічному рівню, або наукова (викладацька) робота;

2. Залученням світових експертів, тренерів, наставників, європейської мережі підприємництва шкіл обміну досвідом та національних ресурсів 3 навчання підприсмництву та інноваціям, зокрема мережі підвищення кваліфікації як для викладачів, так і для керівників закладів вищої освіти та наукових установ:

3.Покращення якості освіти шляхом наближення іï до потреб глобального ринку та потреб у фахівцях, здатних створювати, адаптувати та використовувати технологічні інновації. досягнень науково-технічного прогресу у виробництво і соціальну сореру, що охоплює: випуск і поширення принципово нових видів техніки та технологій; прогресивні міжгалузеві структурні зрушення; реалізацію довгострокових науково-технічних програм 3 великими строками окупності витрат; фрінансування фрундаментальних досліджень для здійснення якісних змін у стані продуктивних сил; розробку і впровадження нової, ресурсозберігаючої технології, призначеної для поліпшення соціального і екологічного становища. 
Таблиця 1

Нормативно правові акти, що регулюють інноваційну діяльність в Україні

\begin{tabular}{|c|c|c|}
\hline & $\begin{array}{l}\text { Нормативно- } \\
\text { правовий акт }\end{array}$ & Основні положення \\
\hline 1 & $\begin{array}{l}\text { Конституція } \\
\text { України }\end{array}$ & $\begin{array}{l}\text { Ст. } 54 \text { гарантує громадянам свободу наукової і технічної, а також } \\
\text { інших видів творчості, захист інтелектуальної власності, їхніх автор- } \\
\text { ських прав. Держава сприяє розвиткові науки, встановленню науко- } \\
\text { вих зв'язків України зі світовим співтовариством. }\end{array}$ \\
\hline 2 & $\begin{array}{c}\text { Господарський } \\
\text { кодекс України } \\
\text { від 16.01.2003 р. }\end{array}$ & $\begin{array}{l}\text { Розділ } 34 \text { Кодексу регулює інноваційну діяльність, як вид господар- } \\
\text { ської діяльності }\end{array}$ \\
\hline 3 & $\begin{array}{c}\text { Закон України } \\
\text { «Про спеціальний } \\
\text { режим іннова- } \\
\text { ційної діяльності } \\
\text { технологічних } \\
\text { парків» }\end{array}$ & $\begin{array}{l}\text { Визначає правові та економічні засади запровадження та фрункціо- } \\
\text { нування спеціального режиму інноваційної діяльності технологічних } \\
\text { парків }\end{array}$ \\
\hline 4 & $\begin{array}{c}\text { Закон України } \\
\text { «Про інвестиційну } \\
\text { діяльність» }\end{array}$ & $\begin{array}{l}\text { Визначає загальні правові, економічні та соціальні умови інвестицій- } \\
\text { ної діяльності на території України }\end{array}$ \\
\hline 5 & $\begin{array}{l}\text { Закон України } \\
\text { «ро інноваційну } \\
\text { діяльність» }\end{array}$ & $\begin{array}{l}\text { Забезпечує взаємодію науки, освіти, виробництва, фрінансово-кре- } \\
\text { дитної сфрери у розвитку інноваційної діяльності; } \\
\text { едективне використання ринкових механізмів для сприяння інно- } \\
\text { ваційній діяльності, підтримка підприємництва у науково-виробничій } \\
\text { сфрері тощо). }\end{array}$ \\
\hline 6 & $\begin{aligned} & \text { Закс } \\
& \ll \sqcap p c \\
& \text { цільов }\end{aligned}$ & $\begin{array}{l}\text { изначає засади розроблення, затвердження та виконання держав- } \\
\text { хх цільових програм (в тому числі і програм пов'язаних з інновацій- } \\
\text { ю діяльністю). }\end{array}$ \\
\hline 7 & $\begin{array}{c}\text { Закон України } \\
\text { «ро державне } \\
\text { регулювання } \\
\text { діяльності у } \\
\text { сфрері трансферу } \\
\text { технологій» }\end{array}$ & $\begin{array}{l}\text { Визначає правові, економічні, організаційні та фрінансові засади дер- } \\
\text { жавного регулювання діяльності у сфері транссреру технологій і } \\
\text { спрямований на забезпечення есективного використання науково- } \\
\text { технічного та інтелектуального потенціалу України, технологічності } \\
\text { виробництва продукції, охорони майнових прав на вітчизняні техно- } \\
\text { логії на території держав, де планується або здійснюється їх вико- } \\
\text { ристання, розширення міжнародного науковотехнічного співробітни- } \\
\text { цтва у цій сфері. }\end{array}$ \\
\hline 8 & $\begin{array}{c}\text { Закон України } \\
\text { «Про пріоритетні } \\
\text { напрямки } \\
\text { інноваційної } \\
\text { діяльності } \\
\text { в Україні» }\end{array}$ & $\begin{array}{l}\text { Закріплює правові, економічні та організаційні засади орормування } \\
\text { цілісної системи пріоритетних напрямів інноваційної діяльнсті та } \\
\text { їх реалізації в Україні забезпечення інноваційної моделі розвитку } \\
\text { економіки шляхом концентрації ресурсів держави на пріоритетних } \\
\text { напрямах науково-технічного оновлення виробництва, підвищення } \\
\text { конкурентоспроможності вітчизняної продукції на внутрішньому і } \\
\text { зовнішньому ринках }\end{array}$ \\
\hline 9 & $\begin{array}{l}\text { Закон України } \\
\text { «Про наукову і } \\
\text { науково-технічну } \\
\text { експертизу» }\end{array}$ & $\begin{array}{l}\text { Визначає правові, організаційні і фрінансові основи експертної діяль- } \\
\text { ності в науково-технічній сфері, а також загальні основи і принципи } \\
\text { регулювання суспільних відносин у галузі організації та проведення } \\
\text { наукової та науково-технічної експертизи з метою забезпечення } \\
\text { наукового обгрунтування структури і змісту пріоритетних напрямів } \\
\text { розвитку науки і техніки, наукових, науково-технічних, соціально- } \\
\text { економічних, екологічних програм і проектів, визначення напрямів } \\
\text { науково-технічної діяльності, аналізу та оцінки ефективності вико- } \\
\text { ристання науково-технічного потенціалу, результатів досліджень }\end{array}$ \\
\hline 10 & $\begin{array}{l}\text { Закон України } \\
\text { «Про наукову і } \\
\text { науково-технічну } \\
\text { діяльність» }\end{array}$ & $\begin{array}{l}\text { Визначає правові, організаційні та фрінансові засади фоункціонування } \\
\text { і розвитку у сфері наукової і науково-технічної діяльності, створює } \\
\text { умови для провадження наукової і науково-технічної діяльності, } \\
\text { задоволення потреб суспільства і держави у технологічному розви- } \\
\text { тку шляхом взаємодії освіти, науки, бізнесу та влади }\end{array}$ \\
\hline
\end{tabular}

Джерело: розроблено автором на основі [2; 3; 4; 5; 6; 7; 8; 9; 10; 11] 
У межах Господарського кодексу України інноваційна діяльність розглядається лише у ссрері господарювання та визначається як діяльність учасників господарських відносин, що здійснюється на основі реалізації інвестицій з метою виконання довгострокових науковотехнічних програм 3 тривалими строками окупності витрат і впровадження нових науковотехнічних досягнень у виробництво та інші сорери суспільного життя [3].

Наявні невідповідності у законодавстві спричиняють суттєві незручності під час ведення інноваційної діяльності суб'єктами господарювання, а крім того, залишають законодавчо неврегульованою ланку «виникнення та розробки нових знань», зумовлюючи проблеми у стимулюванні інноваційної діяльності, наданні й застосуванні пільг та у правильному тлумаченні нормативно-правових документів, які регулюють цей процес. Недостатня конкретизація ключових напрямів, визначених Законом України «Про пріоритетні напрями інноваційної діяльності в Україні» [9], їх неузгодженість 3 основними напрямами науково-технічної діяльності не сприяють розвитку високоукладної економіки України та не дозволяють запровадити для різних іiї рівнів відповідні механізми реалізації.

Отже, нормативно-правового забезпечення інноваційної діяльності повинно охоплювати правові норми різної галузевої належності, якими регулюються відносини, що виникають у процесі організації та здійснення інноваційної діяльності, відповідати світовим вимогам і перебувати в авангарді стимулювання ведення господарської діяльності в науково-технологічних галузях економіки.

Саме нормативно-правове забезпечення інноваційного розвитку $є$ першим кроком у подоланні диспропорцій в економіці нашої держави та становленні інноваційної моделі розвитку економіки.

Наступним, не менш важливим кроком на шляху реалізації Стратегії $€$ вдосконалення інноваційної інфрраструктури та розширення зв'язків вітчизняних науковців і винахідників 3 вітчизняними та іноземними підприємствами, які активно впроваджують інновації у своїй діяльності.

Створення інсрраструктурного забезпечення для стабільного функціонування інноваційних галузей підприємництва в Україні $€$ на сьогодні найбільш актуальним питанням. Щоб зрозуміти, як само інноваційна інорраструктура може вплинути на досягнення цілей закладених в Стратегії розглянемо більш детальніше, що вона собою являє.

Згідно з Законом України «Про інноваційну діяльність» до інноваційної інфрраструктури відноситься сукупність підприємств, організацій, установ, їх об'єднань, асоціацій будь-якої форми власності, що надають послуги з інноваційної діяльності (фрінансові, консалтингові, маркетингові, інорормаційно-комунікативні, юридичні, освітні тощо) [6].

Широке коло суб'єктів, які складають інституційну основу інноваційної інфрраструктури, виконують різні за своїм фрункціональним призначенням завдання, забезпечуючи її цілісність та комплексне функціонування. У науковій літературі до них відносять різні за своєю організаційно-правовою природою та спеціалізацією суб'єкти господарювання: технологічні та наукові парки, технополіси, стартапи, венчурні фонди, бізнес-інкубатори, центри транссреру технологій, центри комерціалізації, біржі інтелектуальної власності тощо [13].

Видове розмаїття системи суб'єктів інноваційної інфрраструктури дає можливість здійснювати різного роду забезпечення та обслуговування інноваційної діяльності, зокрема, матеріально-технічне (виробниче), фрінансове, інорормаційно-кадрове. Проте неузгоджена робота між ними створює значні перешкоди для ефективного розвитку інноваційної сорери.

На сьогоднішній день для ефективного фрункціонування відповідної системи важливим впровадження ряду заходів, які забезпечать її ефрективне фрункціонування. На нашу думку такими заходами є:

1. Створення цілісної та узгодженої інноваційної інфррастуктури, інститути якої, могли б забезпечувати кругообіг матеріальних, фрінансових та інтелектуальних потоків, а також регулювати раціональні економічні відносини між суб'єктами господарювання. Саме узгоджена робота та взаємодія суб'єктів інноваційної інфрраструктури дасть змогу пришвидшити темпи розвитку вітчизняної економіки.

2. Створення нових та підтримка діяльності вже існуючих технопарків, інноваційно-технологічних центрів, наукових парків, міст високих технологій, бізнес-інкубаторів, інноваційно-технологічних та інжинірингових фрірм, малих та середніх інноваційних підприємств.

3. Розвиток та приведення до сучасного рівня виробничо-технологічного і наукового потенціалу країни.

4. Посилення попиту на інновації з боку виробничого сектору, що сприятиме ство- 
ренню та розвитку окремих елементів інфраструктури інноваційної діяльності.

Третім напрямком реалізації Стратегії $€$ підвищення інноваційної культури серед українського суспільства та підприємців зокрема.

Одним 3 основних фракторів активізації інноваційної діяльності $€$ інноваційна культура підприємств та установ, які створюють та впроваджують інновації.

Світовий досвід в сорері управління вказує на те, що сьогодні подолати інноваційну стагнацію лише завдяки інвестиціям неможливо. Виникає потреба в актуалізації використання творчого потенціалу суспільства поряд 3 фрінансовими методами стимулювання інноваційної діяльності. I тому в умовах сьогодення комерційний успіх підприємства залежить насамперед від здатності управлінців забезпечити баланс між творчістю та ефективністю і від застосування стратегій соціального спрямування.

Значення інноваційної культури зростає при переході від індустріальної економіки до економіки знань, у відповідних умовах необхідним $€$ фрормування інноваційної культури в суспільстві в цілому, а також у трудових колективах підприємств та установ зокрема стійкої традиції сприймати нове, здатності й готовності комплексно його використовувати в інтересах загального прогресу. Слід зазначити, що впровадження певних правил та норм, які сприяють формуванню єдності цілей власників, менеджерів і трудового колективу суб'єкта господарювання, значно підвищує конкурентоспроможність і ефективність його діяльності, дає змогу досягати високих результатів.

Економічні трактування інноваційної культури пов'язують із її впливом на мотиваційну сореру діяльності, сприйнятливістю людей до нових ідей, їх готовністю і здатністю щодо створення, підтримки, впровадження нововведень, формування інноваційної економіки. Вона може виступити тією силою, яка сприятиме активному введенню у обіг технічних, продуктових, технологічних, організаційних нововведень. На думку Ящишина І.В. саме ідеї інноваційної культури здатні сорормувати основу створення інноваційного простору для широкого використання досягнень науки і техніки для зменшення соціальної нерівності, подолання бідності, забезпечення доступності освіти, високих технологій, якісної продукції, зростання соціальної справедливості $[14$, c. 96].

У свою чергу Балабанов Л.В. дає наступне визначення інноваційній культурі - це різно- вид організаційної культури, який сфрормулювався за рахунок прагнення людини до кращих та якісних змін у їхньому житті, що $€$ важливим соціальним аспектом суспільного розвитку [15].

Можна сказати, що інноваційна культура $€$ інструментом, який забезпечує сприйнятливість людей до нових ідей, та відображає їх готовність і здібність підтримувати і реалізувати інновації в усіх ссрерах життя.

Інноваційна культура може розглядатися також як комплексний соціальний феномен, який органічно поєднує питання науки, освіти, культури з соціальною i, перш за все, профе-сійної практикою в різних сфрерах спільноти: управлінні, економіці, освіті, культурі.

На нашу думку інноваційна культура - це відношення та сприйняття людиною та суспільством різних нововведень в діапазоні від толерантного відношення до інновацій, що їх оточують до готовності та здатності створення таких інновацій.

Інноваціна культура $€$ важливою складовою реалізації Стратегії, але на даний час розвиток інноваційної культури в Україні гальмує ряд негативних фракторів. Серед основних таких фракторів, ми б хотіли виділити наступні:

1) низький рівень усвідомлення суспільством необхідності його участі у формуванні свого добробуту; 2) страх перед новим та застарілі методи ведення бізнесу; 3) незацікавленість у підвищенні кваліфрікації; 4) відсутність мотивації до інноваційної діяльності.

Економічне зростання та технологічні зміни на думку Й. Шумпетера завжди супроводжуються творчою деструкцією, яка передбачає заміну старого новим, тобто нові галузі перебирають на себе фрункції старих, нові фрірми перехоплють бізнес уже наявних підприємств, нові вміння і технології роблять поточні навички застарілими.

Саме страх перед творчою деструкцією $є$ основною проблемою у розвитку інноваційної культури, оскільки опір людей до чогось нового не дозволяє усвідомити того, що під економічним розвитком слід розуміти не просто процес збільшення кращих машин або освіченіших людей, а й трансорормаційний процес, який передбачає заміну старого новим. Тому економічний розвиток і відбувається у тих країнах, що не бояться змін, та в яких деструкція не блокується підприємцями, які використовують застарілі методи ведення бізнесу та бояться втратити свої економічні привілеї та політичними діячами, які бояться позбутися своєї політичної влади. 
В реаліях сьогодення інноваційна культура стає необхідною складовою сучасної економіки, оскільки саме відусвідомлення суб'єктами економічних відносин взаємозв'язку між впровадженням нових знань і технологій та отриманням вигоди від цього напряму залежить успішність інноваційних процесів. Створення сприйнятливого середовища для отримання нової інсрормації, іiї акумуляції, передачі, розповсюдження, засвоєння, та реалізації, а також комплексна взаємодія інноваційної культури та економічних знань може забезпечити необхідний рівень всіх сторін соціальноекономічного розвитку країни.

Можна сказати, що безпосереднє фрормування інноваційної культури відбувається через створення інноваційно-культурного простору. Основними характеристиками інноваційно-культурного простору є його всезагальність, тобто значимість основних характеристик незалежно від країни, її соціальноекономічного устрою, а також глобальність за масштабами розповсюдження. Інноваційно-культурний простір допомагає розвитку інтелектуального ресурсу суспільства, фрормуванню людського капіталу на основі впровадження елементів інноваційної культури.

Висновки. Отже розглянувши основні завдання, які стоять перед Стратегією та дослідивши основні напрямки досягнення відповідних задач, можна сказати наступне: не достатньо лише окреслити задачі, необхідно ретельно переглянути та вдосконалити ряд оракторів, які прямо чи опосередковано можуть впливати на розвиток інновацій та інноваційної діяльності в Україні.

Незважаючи на те, що Україна взяла курс на становлення економіки інноваційного типу, слід констатувати, що на даному етапі економіка $€$ не інноваційною, а інноваційно орі- єнтованою. Тобто інноваційна спрямованість обрана її основним курсом, досягнення якого стане можливим лише шляхом оновлення сучасних суспільно-політичних і економікоправових базисів, створення нових інститутів та здійснення трансорормаційних процесів в економіці, фрормування якісно нового комплексу галузей, основним ресурсом яких стануть знання та інформація.

На сьогоднішній день існує ще ряд недоліків, які слід усунути для того щоб есрективно розивати інновації в нашій державі. Такими недоліками $€$ відсутність стратегічного мислення, рішень і культури, політичної волі суб'єктів управлінського впливу, ефективно реалізованих комплексних заходів і дій. Також слід зазначити, що серед сучасних проблем основне місце належить налагодженню роботи інноваційної інорраструктури, а саме забезпечити пряму та ефективну співпрацю між науково-дослідними установами та бізнесом.

Також важливим є розвиток інноваційної культури та усвідомлення важливості людського капіталу на шляху розвитку інноваційної діяльності.

Розвиток людського капіталу в інноваційній економіці повинен характеризуватись такими ознаками: створення інноваційних підприємств, до яких залучені науковці тощо; підвищення якості та загальнодоступності навчання, вироблення компенсаційних заходів та впровадження стипендіальних програм; посилення адаптивного потенціалу суб'єктів господарювання через впровадження управлінських інновацій та інноваційних рішень в сорері організації праці, соціальної відповідальності бізнесу, управління змінами; підтримка стажувань і семінарів між вітчизняними підприємствами і освітніми закладами тощо.

\section{СПИСОК ВИКОРИСТАНИХ ДЖЕРЕЛ:}

1. Про схвалення Стратегії розвитку сфери інноваційної діяльності на період до 2030 року: Розпорядження Кабінету Міністрів України; Стратегія від 10.07.2019 № 526-р Верховна рада України. URL: https://zakon.rada.gov.ua/laws/show/526-2019-\%D1\%80\#Text.

2. Конституція України: Закон від 28.06.1996 № 254к/96-BP. Верховна рада України. URL: https://zakon.rada.gov.ua/laws/show/254\%D0\%BA/96-\%D0\%B2\%D1\%80\#Text.

3. Господарський кодекс України: Закон від 16.01.2003 № 436-IV. Верховна рада України. URL: https://zakon.rada.gov.ua/laws/show/436-15\#Text.

4. Про спеціальний режим інноваційної діяльності технологічних парків: Закон України від 16.07.1999 р. № 991-XIV /Верховна рада України. URL: https://zakon.rada.gov.ua/laws/show/991-14\#Text.

5. Про інвестиційну діяльність: Закон України від 18.09.1999 № 1560-XII. Верховна рада України. URL: https://zakon.rada.gov.ua/laws/show/1560-12\#Text.

6. Про інноваційну діяльність: Закон України від 05.12.2012 № 5460-VI. Верховна рада України. URL: https://zakon.rada.gov.ua/laws/main/40-15. 
7. Про державні цільові програми: Закон України від 18.03. 2004 №1621-IV. Верховна рада України. URL: https://zakon.rada.gov.ua/laws/show/1621-15\#Text.

8. Про державне регулювання діяльності у ссрері трансфреру технологій: Закон України від 14.09.2006 № 143-V. Верховна рада України. URL: https://zakon.rada.gov.ua/laws/show/143-16\#Text.

9. Про пріоритетні напрямки інноваційної діяльності в Україні: Закон України 08.09.2011 № 3715-VI. Верховна рада України. URL: https://zakon.rada.gov.ua/laws/show/3715-17\#Text.

10. Про наукову і науково-технічну експертизу: Закон України від 10.02.1995 № 51/95-ВР. Верховна рада України. URL: https://zakon.rada.gov.ua/laws/show/51/95-\%D0\%B2\%D1\%80\#Text.

11. Про наукову і науково-технічну діяльність: Закон України від 26.11.2015 № 848-VIII. Верховна рада України. URL: https://zakon.rada.gov.ua/laws/show/848-19\#Text.

12. Малойван В.В. Інноваційна інфрраструктура: методологічні засади правового регулювання. Право та інновації. 2015. № 2 (10). C. 43-48. URL: https://ndipzir.org.ua/wpcontent/uploads/2016/06/Maloivan10.pdf.

13. Ящишина І.В. Розвиток інноваційної культури суспільства: проблеми та перспективи. Матеріали $\checkmark$ науково-практичної конференції 21 травня 2010 р. Сімферополь. Центр розвитку освіти, науки та інновацій, 2010. 321 c.

14. Балабанова Л.В., Сардак О.В. Організація праці менеджера : підруч. 2-е вид., перер. та доп. - Київ : ВД «Професіонал», 2007. 416 с.

\section{REFERENCES:}

1. On approval of the Strategy for the development of innovation in the period up to 2030: Order of the Cabinet of Ministers of Ukraine; Strategy dated July 10, 2019 № 526-r. The Verkhovna Rada of Ukraine. Available at: https://zakon.rada.gov.ua/laws/show/526-2019-\%D1\%80\#Text.

2. The Constitution of Ukraine, Law of 28.06.1996 № 254k/96-VR. The Verkhovna Rada of Ukraine. Available at: https://zakon.rada.gov.ua/laws/show/526-2019-\%D1\%80\#Text.

3. Commercial Code of Ukraine: Law of 16.01.2003 № 436-IV. The Verkhovna Rada of Ukraine. Available at: https://zakon.rada.gov.ua/laws/show/436-15\#Text.

4. On the special regime of innovative activity of technology parks: Law of Ukraine of 16.07.1999 № 991-XIV. The Verkhovna Rada of Ukraine. Available at: https://zakon.rada.gov.ua/laws/show/991-14\#Text.

5. On investment activity: Law of Ukraine of September 18, 1999 № 1560-XII. Verkhovna Rada of Ukraine. Available at: https://zakon.rada.gov.ua/laws/show/1560-12\#Text.

6. On innovation activity: Law of Ukraine of 05.12.2012 № 5460-VI. Verkhovna Rada of Ukraine. Available at: https://zakon.rada.gov.ua/laws/main/40-15.

7. On state target programs: Law of Ukraine of 18.03. 2004 №1621-IV / The Verkhovna Rada of Ukraine. URL: https://zakon.rada.gov.ua/laws/show/1621-15\#Text.

8. On state regulation of activities in the field of technology transfer: Law of Ukraine of 14.09.2006 № 143-V. Verkhovna Rada of Ukraine. Available at: https://zakon.rada.gov.ua/laws/show/143-16\#Text.

9. On priority areas of innovation in Ukraine: Law of Ukraine 08.09.2011 № 3715-VI. Verkhovna Rada of Ukraine. Available at: https://zakon.rada.gov.ua/laws/show/3715-17\#Text.

10. On scientific and scientific-technical expertise: Law of Ukraine of 10.02.1995 № 51/95-VR. Verkhovna Rada of Ukraine. Available at: https://zakon.rada.gov.ua/laws/show/51/95-\%D0\%B2\%D1\%80\#Text.

11. On scientific and scientific-technical activity: Law of Ukraine of 26.11.2015 № 848-VIII. Verkhovna Rada of Ukraine. Available at: https://zakon.rada.gov.ua/laws/show/848-19\#Text.

12. Maloyvan V.V. (2015) Innovation infrastructure: methodological principles of legal regulation. Law and Innovation, no. 2 (10), pp. 43-48. Available at: https://ndipzir.org.ua/wpcontent/uploads/2016/06/Maloivan10.pdf.

13. Yashchyshyna I.V.(2010). Development of innovative culture of society: problems and prospects. Proceedings of the V scientific-practical conference on May 21, 2010. Simferopol. Center for Education, Science and Innovation Development, $321 \mathrm{p}$.

14. Balabanova L.V., Sardak O.V. (2007) Organization of work of the manager: textbook, 2nd ed., Break. and ext. Kyiv: VD «Professional», $416 \mathrm{p}$. 